\title{
ISOLATION AND IDENTIFICATION OF PATHOGENIC STRAINS OF STREPTOMYCES ACIDISCABIES FROM NETTED SCAB LESIONS OF POTATO TUBERS IN HOKKAIDO (JAPAN)*
}

\author{
L. TÓTH $^{1,2 * *}$, M. MAEDA ${ }^{1}$, F. TANAKA $^{3}$ AND K. KOBAYASHI ${ }^{1}$ \\ ${ }^{1}$ Graduate School of Agriculture, Hokkaido University, Sapporo, Japan \\ ${ }^{2}$ Department of Microbiology, Eötvös Loránd University, \\ Múzeum körút 4/a, H-1088 Budapest, Hungary \\ ${ }^{3}$ Hokkaido Prefectural Tokachi Agricultural Experimental Station, Sapporo, Japan
}

(Received: March 14, 2001; accepted: April 18, 2001)

A relatively homogeneous group of streptomycete isolates was obtained from netted scab lesions of potato tubers collected from a potato field in Hokkaido, Japan. Based on 55 phenotypic data of 72 Streptomyces strains selected from these isolates together with spectral data on their soluble pigments and with data of a PCR analysis, using species specific primers, these netted scab causing pathogenic organisms were identified as $S$. acidiscabies. S. acidiscabies had previously been isolated from deep (common) scab lesions in the USA and reported as thaxtomin A producer. In contrast, our S. acidiscabies strains were not able to induce deep scab symptoms on potato minitubers in pot test, did not produce the phytotoxin thaxtomin $\mathrm{A}$ and did not contain the pathogenicity related gene, nec-1.

Keywords: netted scab, potato, S. acidiscabies, thaxtomin A, nec-1

Potato scab diseases are responsible for serious economical losses in the potato production of the developed countries. Scab pathogens attack growing potato tubers and/or other underground structures of potato plants. Two types of potato scab diseases can be distinguished: common (deep) scab and netted scab diseases. Common scab is

\footnotetext{
* This paper was written to commemorate to the fiftieth anniversary of the foundation of the Hungarian Society for Microbiology.

** Corresponding author
} 
characterized by erumpent or deep-pitted corky lesions on potato tubers, while netted scab diseases can be characterized by superficial reticulations on the surface of tubers. Common scab is more important in the table crop production than netted scabs because it is more prevalent and scab lesions may extend deep into the tuber tissues.

S. scabies is the predominant common scab pathogen and it is present in all potato producing areas of the world [1-4]. S. acidiscabies and S. turgidiscabies have also been reported as the causative agents of common scab disease in the USA and Japan, respectively [5-7]. Beside these species other streptomycetes have also been reported as the causative agents of common (deep), russet, netted or other types of superficial scab lesions on potato tubers $[3,8,9]$.

Recently, novel types of phytotoxins, designated as thaxtomins, have been isolated and identified from potato tuber tissues attacked by S. scabies. Thaxtomins are cyclized dipeptides composed of N-methylated L-4-nitrotrypto-phyl and variously hydroxylated, N-methylated L-phenylalanyl moieties [10]. Thaxtomin A is the main phytotoxic compound of potato common scab-pathogenic Streptomyces species [11], while thaxtomin C is produced by S. ipomoeae the causative agent of soil rot of sweet potato [12].

Bukhalid and Loria identified a pathogenicity related gene, nec-1 from $S$. scabies [13]. They showed a positive correlation between the thaxtomin A production of 43 strains of three common scab-pathogenic Streptomyces species and (with one exception) the presence of nec-1 gene [14]. More recently, Healy et al. [15] reported on txtAB genes which encode a peptide synthetase required for thaxtomin A production and pathogenicity in common scab-pathogenic Streptomyces species.

In the area of the island Hokkaido $S$. scabies and $S$. turgidiscabies are the predominant common scab pathogens. Tanaka et al. [16] reported on the phenotypic characteristics and pathogenicity of these streptomycetes, Takeuchi et al. [17] reported on their phylogenetic relatedness, while Tóth et al. [18] reported on their thaxtomin A production. However, in the potato experimental field of Hokkaido University common scab disease occurred rarely, while netted scab was detected frequently. From the netted scab lesions of these tubers a streptomycete producing white aerial mycelium was always detected. Production of white arial mycelium on different agar media is not a characteristic feature of $S$. scabies or $S$. turgidiscabies. To identify this novel scab pathogen, we carried out a taxonomical work on the Streptomyces population of these netted-scabbed tubers.

Here we report on the characterization and identification of these Streptomyces strains and on their pathogenicity. 


\section{Materials and methods}

Isolation of streptomycetes from netted scab lesions

Netted scabbed tubers of the potato cultivar Irish Cobbler were collected from the experimental field of Hokkaido University, Japan in 1996 and 1997. Isolation of Streptomyces strains from scabbed tubers was carried out as described by Elesawy and Szabo [1].

Characterization and identification of our netted scab strains

Characterization of strains was carried out by using the diagnostic criteria and standard methods recommended by the ISP (International Streptomyces Project) [19]. For the identification of netted scab strains the species description of Lambert and Loria was used [5].

\section{Reference strains}

The following pathogenic thaxtomin A-producing reference strains were used in this study: S. acidiscabies 84.104 and 84.105 (ATCC 49003 and ATCC 49004) [5] and Streptomyces scabies var. achromogenes strains IV-1, IV-6, V-3, V-20, VI-3, VII-23 [20].

\section{Plant bioassay}

Pathogenicity of our Streptomyces strains was evaluated in the greenhouse. Minitubers generated on stem cuttings were inoculated with a spore suspension of each Streptomyces strains, according to the method of Loria and Kempter [21]. After five days incubation potato tubers were scored for studying the scab lesions.

\section{Thaxtomin A and diffusible pigment production by Streptomyces strains}

Oatmeal broth medium was used for studying the thaxtomin A and/or diffusible pigment production by all of our Streptomyces strains according to the method of Babcock et al. [22]. Briefly, the culture filtrates of strains were extracted by chloroform. The crude chloroform extracts were loaded on precoated Merck DCAlurolle silcagel and developed in chloform/methanol (9:1). Bands comigrating with thaxtomin A standard [18] and/or diffusible pigment standard were recorded. 
Isolation and identification of a pH-sensitive, diffusible pigment of Streptomyces strain S-68 isolated by us from netted scab lesion of potato

Glycerol asparagine broth [19] was used for diffusible pigment production by our netted scab strain S-68. Isolation and purification of the main pigment compound of this strain was carried out as described by King and Lawrence [23]. FAB and FD mass spectra of this compound were obtained on JEOL JMS AX-500 and JEOL JMS SX-102 A mass spectrometers. ${ }^{1} \mathrm{H}$ NMR spectra were obtained for solutions in deuterated methanol and acetone with a Bruker AMX 500 spectrometer operating at $500 \mathrm{MHz}$. Chemical shifts were measured downfield from the signal of internal tetramethylsilane.

DNA isolation from our Streptomyces strains and PCR amplifications of $a \mathrm{~S}$. acidiscabies-specific DNA and the nec-1 gene sequences

Isolation of total DNA from our netted scab Streptomyces strains was carried out according to the method of Rao et al. [24]. PCR amplification of S. acidiscabiesspecific DNA sequence containing the 16S-23S rRNA ITS region from our netted scab strains was carried out as described by Tanaka [25].

For the amplification of nec-1 gene sequence the following primers were used: NEC-5 (f): 5'-GATGAGCGCGAACGGAAG-3' and NEC-3 (r): 5'TTTCTCGTTATCCATATA-3'. PCR amplification was performed in a $50 \mu 1$ reaction mixture (total volume) containing $60 \mathrm{mM}$ Tris- $\mathrm{SO}_{4}(\mathrm{pH} 9.1), 18 \mathrm{mM}\left(\mathrm{NH}_{4}\right)_{2} \mathrm{SO}_{4}, 1.5$ $\mathrm{mM} \mathrm{MgSO}_{4}$, primers $100 \mathrm{ng}$ each, dNTP-s $300 \mu \mathrm{M}$ each, $1 \mu$ template DNA and $1 \mathrm{U}$ Elongase Enzyme Mix (Gibco BRL). Amplification was performed with the following program: DNA denaturing at $94{ }^{\circ} \mathrm{C}$ for $30 \mathrm{sec}$, annealing at $50{ }^{\circ} \mathrm{C}$ for $1 \mathrm{~min}$ and elongation at $72{ }^{\circ} \mathrm{C}$ for $2 \mathrm{~min}$ for 35 cycles. PCR products were examined with agarose gel electrophoresis, using $0.8 \%$ agarose gels in TAE buffer. Gels were stained in ethidium bromide and photographed in UV light.

\section{Results}

From netted scab lesions of Irish cobbler potato tubers collected from the experimental field of Hokkaido University 350 Streptomyces isolates were obtained. These isolates proved to be very similar based on their cultural morphological diagnostic properties. They produced sparse, whitish aerial mycelium on oatmeal agar, yellow-brown substrate mycelium and brownish-red diffusible pigment. 72 strains were selected from them for further detailed studies. They produced well-developed white 
aerial mycelium, rectus-flexibilis sporophores and smooth spores on yeast extract-malt extract-, salt starch- and Czapek-Dox agar. They did not produce melanoid pigments on tyrosin agar and on pepton-iron agar. However, on glycerol asparagine medium these strains produced a vast amount of brownish-red, diffusible pigment that turned yellow when it was acidified with $0.1 \mathrm{~N} \mathrm{HCl}$ and became red when it was treated with $0.1 \mathrm{~N}$ $\mathrm{NaOH}$. These netted scab strains behaved similarly as to their physiological biochemical properties, too. These strains could utilize all ISP (International Streptomyces Project) carbon compounds (L-arabinose, D-fructose, D-glucose, Lrhamnose, sucrose, D-xylose and meso-inositol) as sole C-sources in the medium, except raffinose. From the studied nitrogen sources they utilized L-histidine, Lhydroxiproline, L-valine but they were not able to utilize L-phenylalanine or Lmethionine. They could grow in the presence of $10 \mu \mathrm{g} / \mathrm{ml}$ thallium acetate or $4 \%$ of $\mathrm{NaCl}$. These strains could grow at $\mathrm{pH} 4.0$ and on agar media containing $100 \mu \mathrm{g} / \mathrm{ml}$ potassium tellurite. Growth did not occur in the presence of $10 \mu \mathrm{g} / \mathrm{ml}$ sodium azide, $1 \mu \mathrm{g} / \mathrm{ml}$ crystal violet, $0.1 \%$ phenol or $7 \% \mathrm{NaCl}$. Based on these properties 70 strains out of 72 representative netted scab strains were identified as S. acidiscabies (Table I).

The pathogenicity of our strains was tested in the greenhouse. None of the $S$. acidiscabies strains isolated by us from netted scab lesions was able to induce common (deep) scab lesions on minitubers, while all thaxtomin A producing reference Streptomyces strains caused typical common scab lesions on minitubers under the same greenhouse conditions (Fig. 1).

All Streptomyces strains were screened for phytotoxin production. Although we were not able to detect thaxtomin A production in oatmeal broth by our netted scab strains, production of a red, diffusible pigment was always recorded. We isolated the $\mathrm{pH}$-sensitive pigments of our netted scab strain S-68 and characterized them by spectral means. The main pigment compound of this strain had a mw of 338 and had identical ${ }^{1} \mathrm{H}$ NMR spectra with the naphthoquinone derivative produced by $S$. acidiscabies 84.104 [23]. Production of the same pigment by our other netted-scab strains verified their identity (Fig. 2).

The specific identity of the netted scab strains was checked by PCR analysis. The $836 \mathrm{bp}$, S. acidiscabies-specific sequence was amplified from 8 randomly selected netted scab strains and from two authentic, thaxtomin A producing $S$. acidiscabies strains (Fig. 3).

The pathogenicity related gene, nec-1 (663 bp) was amplified from $S$. scabies var. achromogenes VII-23 strain and from two authentic $S$. acidiscabies strains $(84.104$ and 84.105). In contrast, we were not able to amplify the same sequence from our $S$. acidiscabies strains isolated from netted scab lesions in Hokkaido (Fig. 4). 
Table I

Comparison of selected diagnostic properties of 70 representative $\mathrm{S}$. acidiscabies strains isolated from netted scab lesions of potato tubers in Hokkaido with the type strain of $\mathrm{S}$. acidiscabies (ATCC 49003)

\begin{tabular}{|c|c|c|}
\hline Characteristics & $\begin{array}{l}\text { Type strain of } \\
\text { S. acidiscabies } \\
\text { (ATCC 49003) }\end{array}$ & $\begin{array}{c}\text { Data on } 70 \text { strains of } \\
\text { S. acidiscabies from } \\
\text { Hokkaido }\end{array}$ \\
\hline \multirow{2}{*}{$\begin{array}{l}\text { Colour of aerial mycelium } \\
\text { substrate mycelium }\end{array}$} & White-series & White-series \\
\hline & Yellow-brown & Yellow-brown \\
\hline Soluble pigment & Red/yellow & Red/yellow \\
\hline Spore chain morphology & Rectus & Rectus \\
\hline Spore surface (EM obs.) & Smooth & Smooth \\
\hline Melanoid pigments & - & - \\
\hline \multicolumn{3}{|l|}{ Carbon source utilization } \\
\hline L-Arabinose & + & + \\
\hline D-Fructose & + & + \\
\hline D-Glucose & + & + \\
\hline D-Mannitol & + & + \\
\hline Raffinose & - & - \\
\hline L-Rhamnose & + & + \\
\hline Sucrose & + & + \\
\hline D-Xylose & + & + \\
\hline meso-Inositol & + & + \\
\hline Minimum $\mathrm{pH}$ for growth & 4.0 & 4.0 \\
\hline \multicolumn{3}{|l|}{ Growth in the presence of } \\
\hline Thallium acetate $(100 \mu \mathrm{g} / \mathrm{ml})$ & - & - \\
\hline Thallium acetate $(10 \mu \mathrm{g} / \mathrm{ml})$ & + & + \\
\hline Sodium chloride $(7 \%$, wt/vol $)$ & - & - \\
\hline Christal violet $(100 \mu \mathrm{g} / \mathrm{ml})$ & - & - \\
\hline Penicillin G (10 IU/ml) & + & + \\
\hline Phenol $(0.1 \%, \mathrm{wt} / \mathrm{vol})$ & + & - \\
\hline Streptomycin $(20 \mu \mathrm{g} / \mathrm{ml})$ & + & + \\
\hline
\end{tabular}

\section{Discussion}

Due to the contradictory data on potato scab-pathogenic Streptomyces species (as to their various characteristic diagnostic features, the different scab symptoms they induce and the different ecological conditions under which they operate) their taxonomical status was obscure for a long time [1,3]. With the cumulating data on streptomycetes causing common (deep) scab disease and with the application of molecular biological technics in microbial systematics, it became clear that $S$. scabies is the predominant common (deep) scab pathogen all over the world [6, 17]. However S. acidiscabies, S. turgidiscabies S. albidoflavus, S. rochei, etc., are also scab 
pathogens (common or netted scab inducers) [8], but their geographical distribution is restricted.

Fig. 1. Common (deep) scab symptoms on potato minitubers inoculated with $S$. scabies var. achromogenes VII-23 strain (left) and with thaxtomin A producing, nec-1 positive $S$. acidiscabies 84.104 reference strain (centre) compared with a minituber inoculated by $S$. acidiscabies $\mathrm{S}-71$ strain isolated from netted scab in Hokkaido (right)

Fig. 2. Pigment and thaxtomin A production of Streptomyces strains. Lane 1, Thaxtomin A standard, lane 2, diffusible pigment standard., lanes 3-7, S. scabies var. achromogenes IV-1, IV-6, V-3, V-20, VI-3 strains isolated from common (deep) scab lesions, lanes 8-12, S. acidiscabies strains isolated from netted scab lesions in Hokkaido 
Fig. 3. PCR amplification of a $S$. acidiscabies-specific DNA sequence ( $836 \mathrm{bp}$ ) from Streptomyces strains. Lane 1, $\lambda$ DNA digested with Hind III, lanes 2-5, and 14-17 belong to Streptomyces strains isolated from netted scab lesions, lanes 6-7, S. acidiscabies 84.104 and 84.105 reference strains and lanes 8-13, S. scabies var. achromogenes IV-1, IV-6, V-3, V-20, VI-3, VII-23 strains

Demonstration of the role of phytotoxins thaxtomins in the etiology of potato common scab disease and thaxtomin A production by S. scabies, S. acidiscabies and $S$. turgidiscabies led to the plausible explanation how these taxonomically distinct pathogenic species are able to cause the same disease $[10,11]$. The same pathogenicity mechanism suggested the possibility of horizontal transfer of pathogenicity genes among scab pathogenic streptomycetes. Molecular-biological studies proved the determinative role of thaxtomins in scab pathogenesis [15] and provided evidence for the horizontal gene transfer of pathogenicity genes among common scab inducers [14, $15]$.

During our studies on scab pathogenic streptomycetes in Hokkaido we isolated and identified $S$. acidiscabies from netted scab lesions of potato tubers. $S$. acidiscabies was described in the US as a common (deep) scab pathogen $[5,26]$ and reported as thaxtomin A producer [11]. In contrast our S. acidiscabies strains were not able to induce common scab disease. Presumably, this is due to the genetical differences between the American and Japanese $S$. acidiscabies strains. In fact our S. acidiscabies 
strains did not contain the pathogenicity related gene nec-1 moreover they did not produce thaxtomin A.

Fig. 4. PCR amplification of nec-1 gene (663 bp) from Streptomyces strains. Lane 1, $\lambda$ DNA digested with Hind III, lane 2, S. scabies var. achromogenes VII-23 strain., lanes 3 and 4 S. acidiscabies 84.104 and 84.105 reference strains and lanes 5-10, S. acidiscabies strains isolated from netted scab lesions of potato in Hokkaido

Our results agree with those of Kreuze et al. [27]. These authors reported on non-pathogenic $S$. turgidiscabies strains isolated in Finnland, which were nec-1 negative. Although they did not present data on the thaxtomin A production of their non-pathogenic $S$. turgidiscabies strains, it is very probable that non-pathogenic variants of potato scab inducers are frequent in cultivated soils and these streptomycetes can be transformed into pathogenic ones (netted or common scab inducers) under appropriate soil conditions (via horizontal gene transfer). In the future we will further study the pathogenicity of our netted scab strains to identify those factors which are specifically involved in netted scab formation and make attempts to transform some of these strains with pathogenicity genes described in plant pathogenic streptomycetes.

Acknowledgement. We would like to thank Professor Hisanori Bando (Department of Applied Bioscience, Hokkaido University, Sapporo, Japan) for providing conditions necessary for molecular- 
biological work. We also thank Mr Kenji Watanabe for the mass spectral measurments and Dr Eri Fukushi for proton NMR analysis.

\section{References}

1. Elesawy,A.A., Szabo,I.M.: Isolation and characterization of strains from scab lesions of potato. Designation of the neotype strain of Streptomyces scabies. Acta Microbiol Acad Sci Hung 26, 311 (1979).

2. Lambert,D.H., Loria,R.: Streptomyces scabies sp. nov. Int J Syst Bacteriol 39, 387 (1989).

3. Locci,R.: Actinomycetes as plant pathogens. Eur J Plant Pathol 100, 179 (1994).

4. Toth,L.: Distribution and frequency of Streptomyces scabies on the tubers of two scab-susceptible potato cultivars. Acta Phytopathol Entomol Hung 26, 427 (1991).

5. Lambert,D.H., Loria,R.: Streptomyces acidiscabies sp. nov. Int J Syst Bacteriol 39, 393 (1989).

6. Loria,R., Bukhalid, R.A., Fry,B.A., King,R.R.: Plant pathogenicity in the genus Streptomyces. Plant Disease 81, 836 (1997).

7. Miyajima,K., Tanaka,F., Takeuchi,T., Kuninaga,S.: Streptomyces turgidiscabies sp. nov. Int J Syst Bacteriol 48, 495 (1998).

8. Bramwell,P.A., Wiener,P., Akkermans,A.D.L., Wellington,E.M.H.: Phenotypic, genotypic and pathogenic variation among streptomycetes implicated in common scab disease. Lett Appl Microbiol 27, 255 (1998).

9. Scholte,K., Labruyere,R.E.: Netted scab: a new name for an old disease in Europe. Potato Res 28, 443 (1985).

10. King,R.R., Lawrence,C.H., Clark,M.C., Calhoun,M.H.: Isolation and characterization of phytotoxins associated with Streptomyces scabies. J Chem Soc 13, 849 (1989).

11. King,R.R., Lawrence,C.H., Clark,M.C.: Correlation of phytotoxin production with pathogenicity of Streptomyces scabies isolates from scab infected potato tubers. Am Potato J 68, 675 (1991).

12. King, R.R., Lawrence,C.H.: Isolation and characterization of thaxtomin-type phytotoxins associated with Streptomyces ipomoeae. J Agric Food Chem 42, 1791 (1994).

13. Bukhalid,R.A., Loria,R.: Cloning and expression of a gene from Streptomyces scabies encoding a putative pathogenicity factor. J Bacteriol 179, 7776 (1997).

14. Bukhalid,R.A., Loria,R.: nec1, a gene conferring a necrogenic phenotype, is conserved in plantpathogenic Streptomyces spp. and linked to a transposase pseudogene. Mol Plant-Microbe Interaction 11, 960 (1998).

15. Healy,F.G., Krasnoff,S.B., Gibson,D.M., Loria,R.: The txtAB genes of the plant pathogen Streptomyces acidiscabies encode a peptide synthetase required for phytotoxin thaxtomin $\mathrm{A}$ production and pathogenicity. Mol Microbiol 38, 794 (2000).

16. Tanaka,F., Takeuchi,T., Tanii,A., Miyajima,K., Abe,H., Kuninaga,S.: A causal pathogen of scab on potato Streptomyces turgidiscabies n.sp (In Japanese). Ann Phytopathol Soc Jpn 61, 253 (1995).

17. Takeuchi,T., Sawada,H., Tanaka,F., Matsuda,I.: Phylogenetic analysis of Streptomyces spp. Causing potato scab based on 16S rRNA sequences. Int J Syst Bacteriol 46, 476 (1996). 
18. Toth,L., Akino,S., Kobayashi,K., Doi,A., Tanaka,F., Ogoshi,A.: Production of thaxtomin A by Streptomyces turgidiscabies. Soil Microorg 51, 29 (1998).

19. Shirling,E.B., Gottlieb,D.: Methods for characterization of Streptomyces species. Int J Syst Bacteriol 16, 313 (1966).

20. Toth,L., Ogiso,H., Akino,S., Kobayashi,K., Ogoshi.A.: Characteristics of a Streptomyces sp. isolated from common scab lesions of potato. Soil Microorg 48, 45 (1996).

21. Loria,R., Kempter,B.A.: Relative resistance of potato tubers produced from stem cuttings and seedpiece-propagated plants to Streptomyces scabies. Plant Disease 70, 1146 (1986).

22. Babcock,M.J., Eckwall,E.C., Schottel,J.L.: Production and regulation of potato scab inducing phytotoxins by Streptomyces scabies. J Gen Microbiol 139, 579 (1992).

23. King, R.R., Lawrence,C.H.: Isolation and identification of pigments generated in vitro by Streptomyces acidiscabies. J Agric Food Chem 44, 2849 (1996).

24. Rao,R.N., Richardson,M.A., Kuhstoss,S.: Cosmid shuttle vectors for cloning and analysis of Streptomyces DNA. Methods Enzymol 153, 166 (1987).

25. Tanaka,F.: Identification, quantification of potato scab pathogens and control of the disease by changing soil environment. PhD Thesis. Hokkaido University, Sapporo, Japan (1999). (In Japanese).

26. Bonde,M.R., McIntryre,G.A.: Isolation and biology of Streptomyces sp. causing potato scab in soils below pH 5.0. Am Potato J 45, 273 (1968).

27. Kreuze,J.F., Soumalainen,S., Paulin,L., Valkonen,P.J.T: Phylogenetic analysis of $16 \mathrm{~S}$ rRNA genes and PCR analysis of the nec-1 gene from Streptomyces spp. causing common scab and netted scab in Finnland. Phytopathology 89, 462 (1999). 